Article

\title{
Interaction of Nerve Growth Factor $\beta$ with Adiponectin and SPARC Oppositely Modulates its Biological Activity
}

\author{
Yuu Okura ${ }^{1}$, Takeshi Imao ${ }^{1}$, Seisuke Murashima ${ }^{1}$, Haruki Shibata ${ }^{2}$, Akihiro Kamikavwa ${ }^{1}$, \\ Yuko Okamatsu-Ogura ${ }^{1}$, Masayuki Saito ${ }^{1}$ and Kazuhiro Kimura ${ }^{1, *}$ \\ 1 Department of Biomedical Sciences, Graduate School of Veterinary Medicine, Hokkaido University, \\ Sapporo 060-0818, Japan; okura.yuu@icloud.com (Y.O.); t-imao@mfour.med.kyoto-u.ac.jp (T.I.); \\ murashima@daktari.info (S.M.); akami@obihiro.ac.jp (A.K.); y-okamatsu@vetmed.hokudai.ac.jp (Y.O.-O.); \\ ms-consa@krf.biglobe.ne.jp (M.S.) \\ 2 Morinaga Institute of Biological Science, Yokohama 236-0003, Japan; h.shibata@miobs.com \\ * Correspondence: k-kimura@vetmed.hokudai.ac.jp; Tel./Fax: +81-11-757-0703
}

Received: 2 March 2019; Accepted: 25 March 2019; Published: 27 March 2019

\begin{abstract}
Both adiponectin and secreted protein, acidic and rich in cysteine (SPARC) inhibit platelet-derived growth factor-BB (PDGF-BB)-induced and basic fibroblast growth factor (FGF2)-induced angiogenic activities through direct and indirect interactions. Although SPARC enhances nerve growth factor (NGF)-dependent neurogenesis, the physical interaction of NGF $\beta$ with adiponectin and SPARC remains obscure. Therefore, we first examined their intermolecular interaction by surface plasmon resonance method. NGF $\beta$ bound to immobilized SPARC with the binding constant of $59.4 \mathrm{nM}$, comparable with that of PDGF-BB $(24.5 \mathrm{nM})$ but far less than that of FGF2 $(14.4 \mu \mathrm{M})$. NGF $\beta$ bound to immobilized full length adiponectin with the binding constant of $103 \mathrm{nM}$, slightly higher than those of PDGF-BB (24.3 nM) and FGF2 (80.2 nM), respectively. Treatment of PC12 cells with SPARC did not cause mitogen-activated protein kinase (MAPK) activation and neurite outgrowth. However, simultaneous addition of SPARC with NGF $\beta$ enhanced NGF $\beta$-induced MAPK phosphorylation and neurite outgrowth. Treatment of the cells with adiponectin increased AMP-activated protein kinase (AMPK) phosphorylation but failed to induce neurite outgrowth. Simultaneous treatment with NGF $\beta$ and adiponectin significantly reduced cell size and the number of cells with neurite, even after silencing the adiponectin receptors by their siRNA. These results indicate that NGF $\beta$ directly interacts with adiponectin and SPARC, whereas these interactions oppositely regulate NGF $\beta$ functions.
\end{abstract}

Keywords: adiponectin; AMPK; BIAcore; extracellular signal-regulated kinase (ERK); matricellular proteins; neuritogenesis; NGF $\beta$; PC12 cells; Secreted protein; acidic and rich in cysteine (SPARC)

\section{Introduction}

Adiponectin, a member of the $\mathrm{C} 1 \mathrm{q} /$ tumor necrosis factor (TNF)-related proteins, is secreted exclusively by adipocytes. Circulating adiponectin exists in several homo-oligomeric forms consisting of elemental homo-trimeric subunit with a collagen-like triple-helical structure [1-4] and its levels are lower in obese subjects compared with lean subjects [5]. Subjects carrying a missense mutation in the adiponectin gene associated with hypo-adiponectinemia exhibit the phenotype of the metabolic syndrome, including insulin resistance and coronary artery disease $[1-4,6]$. Administration of adiponectin has been shown to be beneficial in animal models of diabetes, obesity and atherosclerosis $[1-4,6]$. 
The hallmark of atherosclerosis is the uncontrolled proliferation and migration of vascular smooth muscle cells, resulting in thickening of the vascular wall [7]. Physiological concentrations of adiponectin significantly suppress both the proliferation and migration of vascular smooth muscle cells induced by platelet-derived growth factor (PDGF)-BB, through direct interaction between adiponectin and PDGF-BB [8]. Moreover, it was also shown that adiponectin binds with basic fibroblast growth factor (FGF2), thereby precluding the biological activity [9].

Matricellular proteins are defined as extracellular matrix (ECM)-associated proteins that have no structural roles in ECM-like collagens and laminins. Secreted protein, acidic and rich in cysteine (SPARC), also known as osteonectin and BM-40, is a collagen-binding matricellular protein that regulates tissue remodeling and repair, morphogenesis and angiogenesis in vivo [10,11]. SPARC also plays pivotal roles in altering cancer cell activity and the microenvironment of tumors as well as in the pathologies of obesity and diabetes [12-14]. Some SPARC functions are mediated by its binding to target molecules and alterations in their biological functions. For example, like adiponectin, SPARC binds to PDGF-AB and PDGF-BB, resulting in inhibiting the ligand binding to their receptors [15]. However, SPARC influences biological activities of FGF2 not through their direct binding $[10,16]$.

SPARC protein has been detected in the brain, mainly in glia and astrocytes [17]. Although no obvious neural defects were observed in SPARC null mice [18], recent findings suggest that SPARC is involved in synaptogenesis [19] and synapse elimination [20] as well as nerve growth factor (NGF)-dependent neurite outgrowth [21,22] and axon regeneration [23]. However, it remains unclear whether SPARC directly interacts with NGF.

NGF is a member of a family of neurotrophic factors, which is responsible for the survival, development and function of basal forebrain cholinergic neuron in the central nervous system and of peripheral sympathetic and embryonic sensory neurons [24]. NGF gene is also expressed in white adipose tissues [25]. NGF expression and secretion in 3T3-L1 adipocyte culture are markedly increased in response to inflammatory cytokine such as TNF [25]. Moreover, circulating NGF levels are upregulated in a group of women with obesity and metabolic syndrome, which are related to a low-grade systemic inflammation [26,27]. As NGF modulates various immune cell functions [28,29], it is likely that NGF plays roles as an inflammatory mediator in adipose tissues, in addition to roles as a neurotrophic factor.

It currently remains unclear whether adiponectin affect biological activity of NGF through physical interaction. Therefore, we examined the interactions of adiponectin and SPARC with NGF using a surface plasmon resonance (SPR) method and their effects on NGF-dependent morphological changes in PC12 rat pheochromocytoma.

\section{Results}

The interactions of PDGF-BB and FGF2 with SPRAC were examined using the SPR method. Infusion of different doses of two growth factors on the surface of immobilized SPARC increased RU, reflecting their binding to the ligand, while the cessation of this infusion decreased RU, reflecting their dissociation from the ligand (Figure $\mathrm{S} 1$ ). An analysis of binding kinetics revealed that $\mathrm{K}_{\mathrm{D}}$ of PDGF-BB was $24.3 \mathrm{nM}$, while that of FGF2 was $14.4 \mu \mathrm{M}$, triple-digit difference from the former (Table 1). On the other hand, the infusion of increasing concentrations of NGF $\beta$ gave clear sensorgrams with a $K_{D}$ of $59.4 \mathrm{nM}$, comparable with that of PDGF-BB.

Table 1. Summary of analyte binding to SPARC.

\begin{tabular}{cccc}
\hline Analytes & Association Constant (ka) & Dissociation Constant (kd) & Binding Constant $\left.\mathbf{K}_{\mathbf{D}}=\mathbf{k d} / \mathbf{k a}\right)$ \\
\hline PDGF-BB & $3.71 \times 10^{4}$ & $9.03 \times 10^{-4}$ & $2.43 \times 10^{-8}$ \\
VEGF-165 & $7.58 \times 10^{4}$ & $4.13 \times 10^{-3}$ & $5.44 \times 10^{-8}$ \\
FGF2 & $1.35 \times 10^{2}$ & $1.95 \times 10^{-3}$ & $1.44 \times 10^{-5}$ \\
TGF $\beta 1$ & $7.90 \times 10^{2}$ & $1.92 \times 10^{-2}$ & $2.43 \times 10^{-5}$ \\
NGF $\beta$ & $1.86 \times 10^{5}$ & $1.10 \times 10^{-2}$ & $5.94 \times 10^{-8}$ \\
\hline
\end{tabular}


Interactions of PDGF-BB and FGF2 with full length adiponectin were also examined and found the $K_{\mathrm{D}}$ of PDGF-BB and FGF2 were $24.5 \mathrm{nM}$ and $80.2 \mathrm{nM}$, respectively (Figure S2, Table 2). Infusion of NGF $\beta$ but not the boiled protein, increased RU in a dose-dependent manner. The $K_{D}$ of NGF $\beta$ to adiponectin was $103 \mathrm{nM}$, comparable to those of PDGF-BB and FGF2. To determine whether the interactions of growth factors with full length adiponectin occurred through its globular region, the SPR analyses with globular adiponectin-immobilized chip were performed. Both PDGF-BB and NGF $\beta$ bound selectively to the chip with $\mathrm{K}_{\mathrm{D}}$ of $70.4 \mathrm{nM}$ and $1260 \mathrm{nM}$, respectively (Figure S2, Table 2).

In order to investigate the effects of the NGF $\beta$ and SPARC interaction on NGF $\beta$-induced neuronal differentiation of PC12 rat pheochromocytoma, we initially examined the NGF $\beta$-dependent activation of $\mathrm{p} 44 / \mathrm{p} 42 \mathrm{MAPK}(\mathrm{ERK} 1 / 2)$ as its phosphorylated state. In the cells, among the neurotrophin receptor genes, mRNAs of TrkA, TrkC and p75NTR but not TrkB were detected (Figure S3A). Addition of NGF $\beta$ to the PC12 culture for 10 min dose-dependently induced the phosphorylation of ERK1/2, whereas neurotrophin (NT)-3 and NT4 failed to stimulate its phosphorylation (Figure S3B), suggesting that NGF $\beta$ activates the ERK signal through a TrkA neurotrophin receptor. Addition of SPARC alone did not change the phosphorylated state of ERK1/2 (Figure 1A). However, simultaneous addition of SPARC with NGF $\beta$ enhanced NGF $\beta$-induced ERK1/2 phosphorylation. Similar to this short-term synergistic effect of SPARC and NGF, simultaneous addition of both for $96 \mathrm{~h}$ enhanced NGF-induced neurite outgrowth; however, SPARC alone did not influence neuritogenesis (Figure 1B).

A
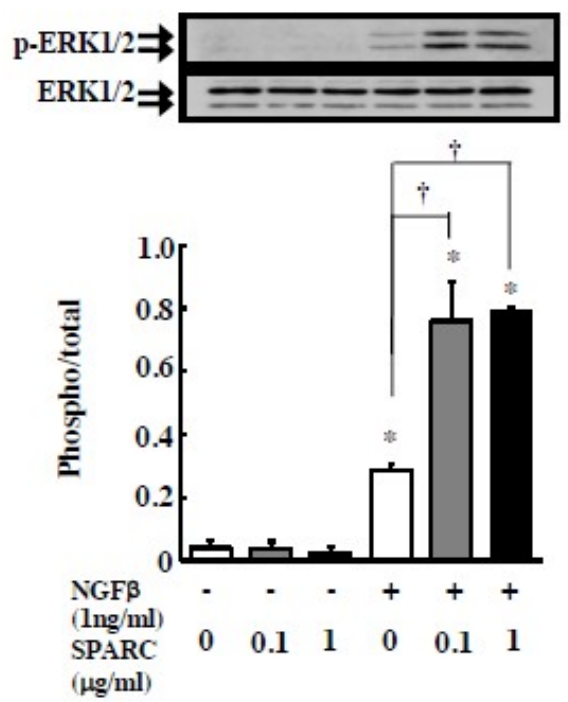

B
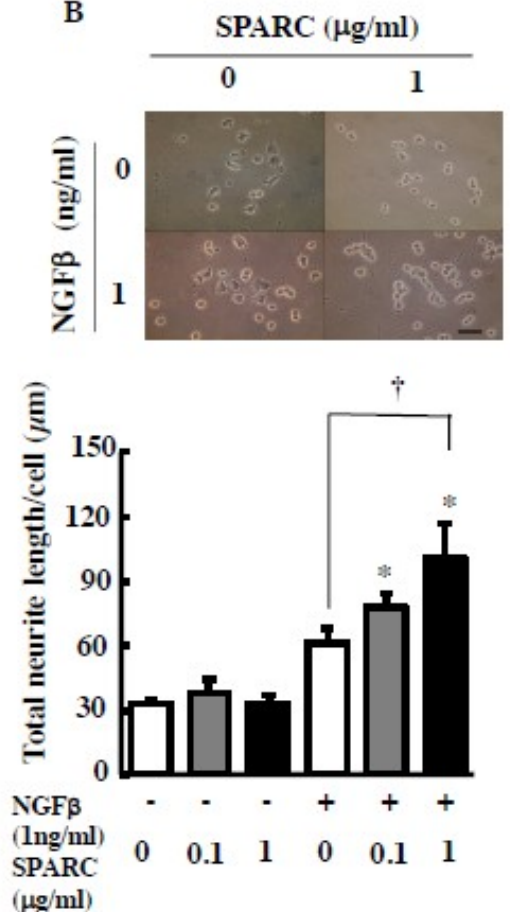

Figure 1. SPARC enhances NGF $\beta$-dependent ERK activation and neurite outgrowth in PC12 cells. (A) PC12 cells were treated with NGF $\beta(1 \mathrm{ng} / \mathrm{mL})$ in the presence or absence of SPARC $(0.1 \mathrm{or} 1 \mu \mathrm{g} / \mathrm{mL})$ for $10 \mathrm{~min}$. Representative results of Western blots for ERK and its phosphorylation are shown in the upper panel, Results from four independent experiments are summarized in the bottom panel. (B) PC12 cells were treated with or without NGF $\beta(0$ or $1 \mathrm{ng} / \mathrm{mL})$ either in the presence or absence of SPARC $(0.1$ or $1 \mu \mathrm{g} / \mathrm{mL})$ for $96 \mathrm{~h}$. Representative results of cells with neurites are shown in the upper panel and results (total neurite length per cell) from three independent experiments are summarized in the bottom. The length of the scale bar in the picture is $50 \mu \mathrm{m}$. ${ }^{*}$ and + indicate significant differences $(p<0.05)$ between no NGF $\beta$ treatment $(0 \mathrm{ng} / \mathrm{mL})$ vs NGF treated and no SPARC treatment $(0 \mu \mathrm{g} / \mathrm{mL})$ vs SPARC treated, respectively. 
Table 2. Summary of analyte binding to adiponectin.

\begin{tabular}{|c|c|c|c|}
\hline Analytes & Association Constant (ka) & Dissociation Constant (kd) & Binding Constant $\left(K_{D}=k d / k a\right)$ \\
\hline & $\begin{array}{l}\text { (ligand: full length } \\
\text { adiponectin) }\end{array}$ & & \\
\hline PDGF-BB & $1.15 \times 10^{3}$ & $2.82 \times 10^{-5}$ & $2.45 \times 10^{-8}$ \\
\hline FGF2 & $7.16 \times 10^{2}$ & $5.76 \times 10^{-5}$ & $8.02 \times 10^{-8}$ \\
\hline \multirow[t]{2}{*}{ NGF $\beta$} & $5.76 \times 10^{4}$ & $5.97 \times 10^{-3}$ & $1.03 \times 10^{-7}$ \\
\hline & $\begin{array}{l}\text { (ligand: globular } \\
\text { adiponectin) }\end{array}$ & & \\
\hline PDGF-BB & $1.05 \times 10^{5}$ & $7.38 \times 10^{-3}$ & $7.04 \times 10^{-8}$ \\
\hline NGF $\beta$ & $1.15 \times 10^{4}$ & $1.45 \times 10^{-2}$ & $1.26 \times 10^{-6}$ \\
\hline
\end{tabular}

We next examined the interaction between NGF $\beta$ and adiponectin in the physiological condition. PC12 cells treated with NGF $\beta$ induced neurite outgrowth as well as enlargement of cell size, while the cells treated with full length adiponectin or globular adiponectin alone did not (Figure 2A). The cells treated simultaneously with NGF $\beta$ and full length adiponectin induced morphological changes of the cells but the degrees of neurite outgrowth (Figure 2B,C) and cell enlargement (Figure 2D) were significantly decreased, compared with those of low-dose NGF $\beta$ alone (e.g., $1 \mathrm{ng} / \mathrm{mL}$ ). It is interesting to note that full length adiponectin failed to suppress high-dose NGF $\beta(20 \mathrm{ng} / \mathrm{mL})$-induced number of cells with neurite (Figure 2A,B). Simultaneous addition of NGF $\beta$ and globular adiponectin also suppressed morphological changes of the cells in some cases but the magnitudes of suppression by globular adiponectin, if present, were less than those induced by full length adiponectin (Figure 2B-D).

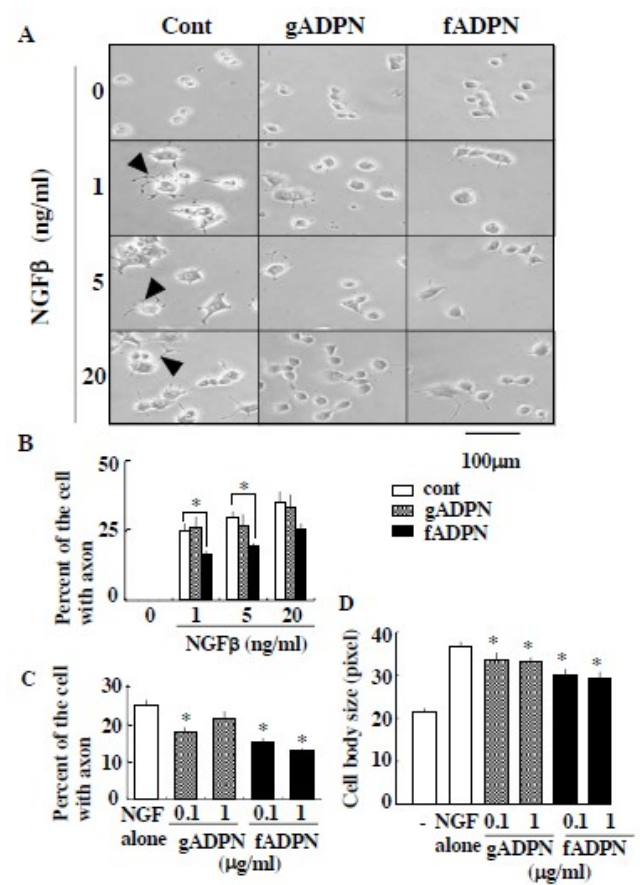

Figure 2. Adiponectin suppressed NGF $\beta$-induced neurite outgrowth and cell swelling. (A,B) PC12 cells were treated with increasing concentration of NGF $\beta$ either in the presence or absence of full-length adiponectin (fADPN, $1 \mu \mathrm{g} / \mathrm{mL}$ ) and globular adiponectin (gADPN, $1 \mu \mathrm{g} / \mathrm{mL}$ ). Representative results of the cells (arrowhead: neurite) are shown in A and results (percentage of the cells with axon) from five independent experiments are summarized in B. (C,D) PC12 cells were treated with NGF $\beta(1 \mathrm{ng} / \mathrm{mL})$ either in the presence or absence of full length adiponectin and globular adiponectin $(0.1 \mathrm{and} 1 \mathrm{~g} / \mathrm{mL})$. The ratio of the cell with axon $(\mathbf{C})$ and the changes in cell body size (D) are determined and summarized from three independent experiments. * indicates the statistically significant difference $(p<0.05)$ from NGF $\beta$ treatment alone (Cont). 
RT-PCR analysis was performed on adiponectin receptors in PC12 cells. As shown in Figure 3A, both AdipoR1 and AdipoR2 mRNA were detected. The cells treated with either full length or globular adiponectin alone did enhance the activity-related site-specific phosphorylation of AMP-activated protein kinase (AMPK) $\propto$ (Figure 3B), indicating the PC12 cells expresses two types of functional adiponectin receptors. To examine whether these receptors' activation was necessary for the adiponectin inhibition of NGF $\beta$ functions, we tested the effect of adiponectin on NGF $\beta$-induced neurite outgrowth in the AdipoR1- and/or AdipoR2-silenced PC12 cells. Transfection of siRNA for either AdipoR1, AdipoR2 or both successfully silenced the respective receptors in mRNA levels (Figure 3C) and AMPK activation (Figure 3D). Treatment of PC12 cells with NGF $\beta$, irrespective of silencing of either AdipoR1 or AdipoR2, induced neurite outgrowth and the addition of full length adiponectin suppressed the effect of NGF $\beta$ (Figure 3E).

A

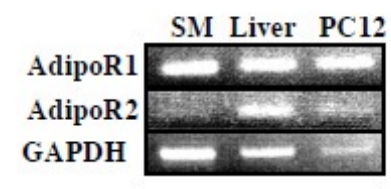

B

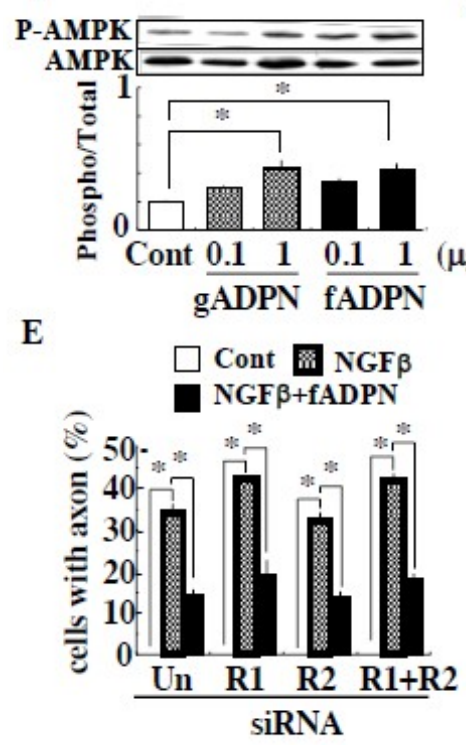

C

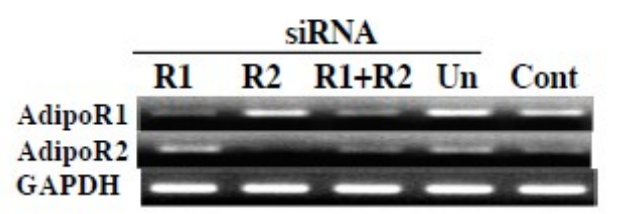

D

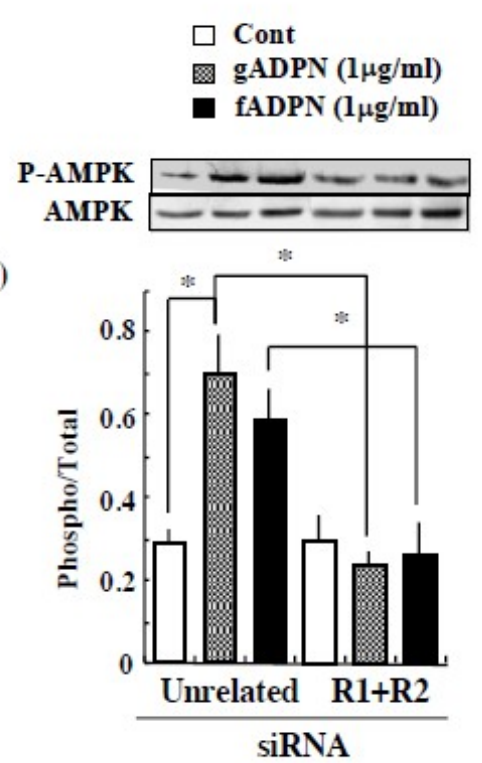

Figure 3. Adiponectin suppressed NGF $\beta$-induced neurite outgrowth independently of its receptor activation. (A) Expression of AdipoR1 and AdipoR2 mRNA in the rat skeletal muscle (SM), liver and PC12 cells are shown. (B) PC12 cells were treated with full length adiponectin or globular adiponectin and the amounts of phosphorylated and total AMPK were determined. Representative results and the ratio of phosphorylated and total AMPK are shown $(n=5)$. (C-E) PC12 cells were treated with unrelated (un), AdipoR1, AdipoR2 and R1 plus R2 siRNA and (C) mRNA expression of AdipoR1 and AdipoR2 are shown. (D) The transfected cells were treated with vehicle (cont.), globular adiponectin $(1 \mu \mathrm{g} / \mathrm{mL})$ and full length adiponectin $(1 \mu \mathrm{g} / \mathrm{mL})$ and the state of AMPK activation are shown $(n=3)$. (E) The transfected cells were treated with vehicle (cont.), NGF $\beta(1 \mathrm{ng} / \mathrm{mL})$ or NGF $\beta$ plus full length adiponectin $(1 \mu \mathrm{g} / \mathrm{mL})$ and the ratios of the cell with axon are shown $(n=3)$. The transfected cells treated with vehicle did not induce any neurite (axon) as shown in Figure 2A and the ratio calculated was 0 as in Figure 2B. Thus, bar for control value of each siRNA was not seen. * indicates the statistically significant difference $(p<0.05)$ from cont. or NGF $\beta$ treatment alone. 


\section{Discussion}

In the present study, we showed the apparent interaction of SPARC with NGF $\beta$, PDGF-BB and FGF2 with the $\mathrm{K}_{\mathrm{D}}$ of $59.4 \mathrm{nM}, 24.3 \mathrm{nM}$ and $14.4 \mu \mathrm{M}$, respectively. As SPARC is reported to interfere with FGF2-induced functions not through direct binding [16], the interaction between SPARC and FGF2 on the sensor chip was unexpected although its $K_{D}$ value was a triple-digit difference from those of two other growth factors tested. Since in vitro binding studies between SPARC and FGF2 were performed by using the RIPA buffer containing various detergents during the washing procedure, this weak interaction might be masked. Similarly, no apparent binding of SPARC to transforming growth factor (TGF) $\beta 1$ is reported by in vitro binding assay [30]. However, we observed weak interaction between SPARC and TGF $\beta 1$ with the $\mathrm{K}_{\mathrm{D}}$ of $24.3 \mu \mathrm{M}$. This weak interaction might also contribute to chimeric TGF-receptor II binding to SPARC, as the binding occurred only in the presence of TGF $\beta 1$ [30]. In contrast, it is reported that SPARC prevents PDGF-induced and vascular endothelial growth factor (VEGF)-induced biological activities through their direct interactions [31]. SPR analysis revealed that SPARC interacted selectively with VEGF- 165 with the $K_{D}$ of $54.4 \mathrm{nM}$. As the $K_{D}$ between SPARC and NGF $\beta$ is almost the same as those of PDGF-BB and VEGF-165, direct binding of NGF $\beta$ to SPARC might be able to influence NGF activity.

Similarly, we demonstrated that NGF $\beta$ but not denatured NGF $\beta$ by boiling, bound to full length adiponectin with the $\mathrm{K}_{\mathrm{D}}$ of $103 \mathrm{nM}$, while those of PDGF-BB and FGF2 were $24.5 \mathrm{nM}$ and $80.2 \mathrm{nM}$, respectively. Different from SPARC, it is reported that adiponectin binds with FGF2 as well as PDGF-BB, thereby precluding their biological activity $[8,9]$. As the interaction between NGF $\beta$ and adiponectin shows comparative $K_{D}$ value with those of PDGF-BB and FGF2, the interaction might also modulate NGF activity. We also showed that NGF $\beta$ bound to globular adiponectin with much greater reduction of $K_{D}$ value ( $>10$-fold), compared with its binding to full length adiponectin. As the $K_{D}$ values between PDGF-BB and either adiponectin were relatively unchanged $(<3$-fold), it is likely that trimeric or a much higher dimensional structure of adiponectin might be necessary for NGF $\beta$ interaction. This lower ability to bind NGF $\beta$ may lead to weaker suppressive activity by globular adiponectin of NGF $\beta$ function.

NGF $\beta$ binds to two different receptors: the TrkA tyrosine kinase receptor with high affinity and the p75 NTR with low affinity [32]. In PC12 cells, NGF $\beta$ activates the ERK signal through the TrkA, that leading to neurite outgrowth [33]. In the present study, we confirmed the NGF $\beta$ activities, whereas SPARC alone did not change the phosphorylated state of ERK $1 / 2$ and subsequent neuritogenesis. However, simultaneous addition of SPARC with NGF $\beta$ enhanced NGF $\beta$-induced ERK1/2 phosphorylation and NGF $\beta$-induced neurite outgrowth. This synergistic effect of SPARC and NGF on neurite outgrowth was also found in superior cervical ganglion neurons and Schwann cells $[21,22]$. The basal forebrain cholinergic system is one of the target neuronal networks for NGF as a survival factor of cholinergic neurons [24]. NGF is also involved in nurturing the peripheral nervous system [34]. On the other hand, SPARC in the brain is suggested to facilitate cholinergic synapse formation [35], whereas other studies show that SPARC antagonizes the synaptogenesis by having, another matricellular protein [19] and triggers a cell-autonomous program of synapse elimination in cholinergic neurons [20]. Collectively, the present results suggest that a direct interaction between SPARC and NGF $\beta$ enhances the biological activity of this growth factor in the central and peripheral nervous systems. However, the mechanism by which the SPARC and NGF $\beta$ interaction enhanced NGF-signals remains obscure and further works are needed to clarify it.

PC12 cells treated with full length adiponectin alone did not induce any morphological changes, while it activated intracellular signal such as AMPK. The cells treated simultaneously with NGF $\beta$ and full length adiponectin induced neurite outgrowth and cell swelling but the degrees of the changes were significantly less than those of NGF $\beta$ alone. In addition, increasing the concentration of NGF $\beta$ prevented suppression by the constant amount of adiponectin, suggesting that at high concentrations of NGF, excess unbound NGF $\beta$ is able to induce neuritogenesis. Moreover, as this adiponectin suppression of NGF $\beta$-dependent morphological changes were seen even after silencing adiponectin 
receptor signaling in PC12 cells, therefore our present results indicate that full length adiponectin interacts with NGF $\beta$, thereby inhibits NGF $\beta$ functions, possibly through interfering its interaction with TrkA, in contrast to SPARC.

The physiological relevance of full length adiponectin and NGF interaction remains to be elucidated. However, it is interesting to note that NGF production in adipocytes is enhanced and adiponectin production is suppressed, by inflammatory stimuli like TNF [25]. In addition, proteases secreted from activated monocytes and/or neutrophils cleave full-length adiponectin to generate globular adiponectin [36]. Supportively, blood NGF levels are upregulated in a group of women with obesity and the metabolic syndrome [26,27], while circulating adiponectin levels are lower in obese subjects [27]. Therefore, in an adipose tissue from obese subjects where inflammation develops, it is likely to occur that the amounts of NGF and full length adiponectin are increased and decreased, respectively and as a consequence dominance of NGF over adiponectin becomes clear. Furthermore, the expression of SPARC is increased in the adipose tissue of obese animals [14]. In such conditions, NGF and SPARC interaction is expected to facilitate recruitment and activation of mast cells [37], that sustain chronic low-grade inflammation within adipose tissue [38] (see also Figure S4). In an adipose tissue from lean subjects, it is plausible that locally produced NGF is associated with full length adiponectin, resulting in the masking of NGF bioactivity (Figure S4).

In summary, we showed that NGF $\beta$ interacted substantially with both SPARC and full length adiponectin and that SPARC enhanced, but adiponectin suppressed, NGF $\beta$-dependent function in PC12 cells. Other than a neurotrophic factor, NGF plays roles in obesity-related inflammation as described above, in the proliferation and survival of various cancers [39,40] and in pain control [41]. Further works should be undertaken to investigate the involvement of NGF interactions with adiponectin and/or SPARC in each NGF-mediated process in detail.

\section{Materials and Methods}

\subsection{Materials}

Recombinant murine full-length adiponectin was purchased from Biovender Laboratory Medicine, Inc. (Bmo, Czech Republic), while recombinant murine globular adiponectin and recombinant human PDGF-BB were purchased from Wako Pure Chemical (Osaka, Japan). NGF $\beta$ from mouse submaxillary glands was bought from Alomone Labs (Jerusalem, Israel). Recombinant human basic FGF was purchased from Acris Antibodies $\mathrm{GmbH}$ (Hiddenhausen, Germany), while recombinant human VEGF-165 was purchased from Becton Dickison (Bedford, MA, USA). Recombinant human TGF $\beta 1$ was purchased from R\&D systems (Minneapolis, MN, USA).

\subsection{Analysis of Protein-Protein Interaction with Surface Plasmon Resonance (SPR) Method}

The interactions of a growth factor with either adiponectin or SPARC were examined using the BIAcore $\mathrm{X}$ instrument (GE healthcare, Tokyo, Japan) and the binding kinetics were analyzed with BIAevaluation software [42,43]. Briefly, full length adiponectin, globular adiponectin or SPARC (Sangi, Tokyo, Japan) as a ligand was immobilized onto the carboxymethylated dextran surface of the CM5 sensor chip, respectively. The relative responses for the immobilized full length and globular adiponectin and SPARC were 2025, 12707 and 3574 resonance units (RU), respectively, where $1000 \mathrm{RU}$ is equivalent to $1 \mathrm{ng}$ of protein $/ \mathrm{mm}^{2}$. The surface of the adiponectin-chip or the SPARC-chip was perfused with HBS-EP buffer (10 mM HEPES, $150 \mathrm{mM} \mathrm{NaCl}$ and $0.005 \%$ Surfactant P20, pH 7.4) at $37^{\circ} \mathrm{C}$ and then with increasing concentrations of a number of growth factors (as analytes) dissolved in buffer at a flow rate of $20 \mu \mathrm{L} / \mathrm{min}$ for $105 \mathrm{~s}$. Following the addition of each analyte, dissociation was evaluated by passing the buffer alone over the chip for $120 \mathrm{~s}$. If an analyte bound to a ligand, the surface showed a change in reflected light, which was directly proportional to the mass bound and measured in arbitrary RU. Based on the dissociation constant $(\mathrm{kd})\left(\mathrm{s}^{-1}\right)$ and association constant $(\mathrm{Ka})\left(\mathrm{M}^{-1} \mathrm{~s}^{-1}\right)$ 
obtained, the binding constant $\mathrm{K}_{\mathrm{D}}(\mathrm{M})$ was calculated by dividing $\mathrm{Kd}$ by Ka. The regeneration of the surface of the sensor chip was performed by injecting $1 \mathrm{M} \mathrm{NaCl}$ at $20 \mu \mathrm{L} / \mathrm{min}$ for $90 \mathrm{~s}$.

\subsection{Assay of Biological Activity of NGF}

Rat pheochromocytoma, PC12 cells were cultured in RPMI1640 medium (Wako) containing 10\% fetal calf serum (FCS), 10\% horse serum. To examine the effects of NGF on their morphological changes (neurite outgrowth and cell swelling), the cells $\left(5 \times 10^{3}\right.$ cells) were cultured on Type I-collagen-coated plates (Iwaki Techno Glass, Chiba, Japan) in RPMI1640 containing 1\% FCS and 1\% horse serum for $24 \mathrm{~h}$ and subsequently cultured with either NGF $\beta$, adiponectin or both for 4 days. To quantify the morphological changes of PC12 cells, at least 100 randomly selected cells per experimental condition were photographed at the same scale under light transmission inverted photomicroscopy. The picture was analyzed using Adobe Photoshop and NIH Image J, a public-domain image processing and analysis program. Changes in cell body length were measured as a marker of cell swelling. Total neurite length measured and number of cells with neurite which length was longer than cell body length counted were used as an indicator of axonal elongation [44].

\subsection{Expression of AdipoR1 and AdipoR2 in PC12 Cells and Their Silencing}

Total RNA was isolated from PC12 cells and rat tissues by the guanidine-isothiocyanate method using ISOgen reagent (Takara, Tokyo, Japan) and RNA ( $2 \mu \mathrm{g})$ was used for reverse transcription. Rat AdipoR1 (GenBank accession number NM 207587), AdipoR2 (NM 001037979) and glyceraldehyde 3-phosphate dehydrogenase (GAPDH) (NM 017008) cDNA were amplified with the primer pairs as follow: AdipoR1 (201bp) Forward: 5'-TGC TTC AAG AGC ATC TTC CG-3', Reverse: 5'-GAA TGA CAG TAG ACG GTG TG-3' (annealing conditions $56^{\circ} \mathrm{C}, 30 \mathrm{~s}, 29$ cycles); AdipoR2 (206bp) Forward: $5^{\prime}$-TCT TCT TGG GAG CCA TTC TC-3', Reverse: $5^{\prime}$-GCA CAC AGA TGA CAA TCA GG-3' $\left(56^{\circ} \mathrm{C}\right.$, 30 s, 29 cycles); GAPDH (453 bp) Forward: 5'-ACC ACA GTC CAT GCC ATC AC-3', Reverse: 5'-TCC ACC ACC CTG TTG CTG TA-3' $\left(62^{\circ} \mathrm{C}, 30 \mathrm{~s}, 27\right.$ cycles).

Expression of AdipoR1 and AdipoR2 were suppressed by treating the cells with siRNA as essentially described by Fujioka et al [45]. In brief, siRNA specific for AdipoR1 and AdipoR2 and unrelated siRNA were transfected with Lipofectamine2000 (Invitrogen, Carlsbad, CA, USA) according to the instruction provided and cultured as described above.

\subsection{MAP Kinase and AMP-Activated Protein Kinase Activation}

PC12 cells were grown to 80\% confluence in RPMI1640 containing 10\% FCS and 10\% horse serum and further cultured in RPMI1640 containing 1\% FCS and 1\% horse serum for $24 \mathrm{~h}$. Subsequently the cells were treated with either vehicle, NGF $\beta$, neurotrophin (NT)-3, NT-4 (Sigma-Aldrich, St. Louis, $\mathrm{MO}, \mathrm{USA}$ ), SPARC or adiponectin for $10 \mathrm{~min}$. The cells were then lysed with the lysis buffer [ $50 \mathrm{mM}$ Hepes (pH 7.5), $150 \mathrm{mM} \mathrm{NaCl}, 5 \mathrm{mM}$ EDTA, $10 \mathrm{mM}$ sodium pyrophosphate, $2 \mathrm{mM} \mathrm{NaVO}_{3}$ containing protease inhibitor mixture (Complete; Boehringer Mannheim, GmbH, Germany) and 1\% (v/v) Nonidet P40], centrifuged at $12,000 \times \mathrm{g}$ for $15 \mathrm{~min}$ at $4{ }^{\circ} \mathrm{C}$ and the supernatant was saved at $-70^{\circ} \mathrm{C}$.

Aliquot of the lysates (15 or $20 \mu \mathrm{g}$ of protein) were separated by SDS-PAGE (10\% gel) and transferred on PVDF membranes (Immobilon, Millipore, Bedford, MA, USA). The membranes were incubated first in a blocking buffer [ $20 \mathrm{mM}$ Tris $/ \mathrm{HCl}$ (pH 7.5), $150 \mathrm{mM} \mathrm{NaCl}$ containing $0.1 \%$ Tween 20 and $5 \%(v / v)$ skimmed milk], then in the buffer containing anti-Erk1/2, anti-phosphorylated Erk1/2 (Thr202/Tyr204), anti-AMPK $\alpha$ or anti-phosphorylated AMPK $\alpha$ (Thr172) antibody (Cell Signaling Technology, Beverly, MA, USA) for $2 \mathrm{~h}$. The bound antibody was detected with horseradish peroxidase-linked secondary antibodies (Zymed Laboratories, South San Francisco, CA, USA) and an enhanced chemiluminescence system (Millipore). The intensity of chemiluminescence for the corresponding proteins was analyzed by NIH Image J. 


\subsection{Statistical Analysis}

Data were expressed as means \pm standard errors of the mean (SEM) and analyzed by ANOVA followed by the Tukey-Kramer post-hoc test. A $p$ value of less than 0.05 was considered statistically significant.

Supplementary Materials: Supplementary materials can be found at http://www.mdpi.com/1422-0067/20/7/ $1541 /$ s1.

Author Contributions: Conceptualization, M.S. and K.K.; Methodology, A.K., Y.O.-O. and K.K.; Software, A.K. and Y.O.-O.; Validation, Y.O., T.I., H.S. and S.M.; Formal Analysis, Y.O., T.I., S.M. and K.K.; Investigation, Y.O., T.I., H.S. and S.M.; Resources, H.S., Y.O.-O. and K.K.; Data Curation, Y.O., T.I. and K.K.; Writing-Original Draft Preparation, Y.O., T.I.; Writing—Review \& Editing, K.K.; Visualization, K.K.; Supervision, M.S. and K.K.; Project Administration, Y.O.-O. and K.K.; Funding Acquisition, K.K.

Funding: This work was supported by the Japan Society for the Promotion of Science (No. 16K08068).

Conflicts of Interest: The authors declare no conflict of interest.

\section{Abbreviations}

$\begin{array}{ll}\text { AMPK } & \text { AMP-activated protein kinase } \\ \text { ECM } & \text { extracellular matrix } \\ \text { ERK } & \text { extracellular signal regulated kinase } \\ \text { FCS } & \text { fetal calf serum } \\ \text { FGF } & \text { fibroblast growth factor } \\ \text { GAPDH } & \text { glyceraldehyde 3-phosphate dehydrogenase } \\ \text { MAPK } & \text { mitogen-activated protein kinase } \\ \text { NGF } & \text { nerve growth factor } \\ \text { NT } & \text { neurotrophin } \\ \text { PDGF } & \text { platelet-derived growth factor } \\ \text { RU } & \text { resonance unit } \\ \text { SPARC } & \text { secreted protein, acidic and rich in cysteine } \\ \text { SPR } & \text { surface plasmon resonance } \\ \text { TGF } & \text { transforming growth factor } \\ \text { TNF } & \text { tumor necrosis factor } \\ \text { VEGF } & \text { vascular endothelial growth factor }\end{array}$

\section{References}

1. Matsuzawa, Y.; Funahashi, T.; Kihara, S.; Shimomura, I. Adiponectin and metabolic syndrome. Arterioscler. Thromb. Vasc. Biol. 2004, 24, 29-33. [CrossRef]

2. Oh, D.K.; Ciaraldi, T.; Henry, R.R. Adiponectin in health and disease. Diabetes Obes. Metab. 2007, 9, 282-289. [CrossRef] [PubMed]

3. Schäffler, A.; Buechler, C. CTRP family: Linking immunity to metabolism. Trends Endocrinol. Metab. 2012, 23, 194-204. [CrossRef]

4. Liu, M.; Liu, F. Regulation of adiponectin multimerization, signaling and function. Best Pract. Res. Clin. Endocrinol. Metab. 2014, 28, 25-31. [CrossRef]

5. Arita, Y.; Kihara, S.; Ouchi, N.; Takahashi, M.; Maeda, K.; Miyagawa, J.; Hotta, K.; Shimomura, I.; Nakamura, T.; Miyaoka, K.; et al. Paradoxical decrease of an adipose- specific protein, adiponectin, in obesity. Biochem. Biophys. Res. Commun. 1999, 257, 79-83. [CrossRef]

6. Kondo, H.; Shimomura, I.; Matsukawa, Y.; Kumada, M.; Takahashi, M.; Matsuda, M.; Ouchi, N.; Kihara, S.; Kawamoto, T.; Sumitsuji, S.; et al. Association of adiponectin mutation with type 2 diabetes: A candidate gene for the insulin resistance syndrome. Diabetes 2002, 51, 2325-2328. [CrossRef] [PubMed]

7. Orlandi, A.; Bochaton-Piallat, M.L.; Gabbiani, G.; Spagnoli, L.G. Aging, smooth muscle cells and vascular pathobiology: Implications for atherosclerosis. Atherosclerosis 2006, 188, 221-230. [CrossRef] [PubMed] 
8. $\quad$ Arita, Y.; Kihara, S.; Ouchi, N.; Maeda, K.; Kuriyama, H.; Okamoto, Y.; Kumada, M.; Hotta, K.; Nishida, M.; Takahashi, M.; et al. Adipocyte-derived plasma protein adiponectin acts as a platelet-derived growth factor-BB-binding protein and regulates growth factor-induced common postreceptor signal in vascular smooth muscle cell. Circulation 2002, 105, 2893-2898. [CrossRef] [PubMed]

9. Wang, Y.; Lam, K.S.L.; Xu, J.U.; Lu, G.; Xu, L.Y.; Cooper, G.J.S.; Xu, A. Adiponectin inhibits cell proliferation by interacting with several growth factors in an oligomerization-dependent manner. J. Biol. Chem. 2005, 280, 18341-18347. [CrossRef]

10. Rivera, L.B.; Bradshaw, A.D.; Brekken, R.A. The regulatory function of SPARC in vascular biology. Cell Mol. Life Sci. 2011, 68, 3165-3173. [CrossRef]

11. Bradshaw, A.D. Diverse biological functions of the SPARC family of proteins. Int. J. Biochem. Cell Biol. 2012, 44, 480-488. [CrossRef] [PubMed]

12. Bradshaw, A.D.; Sage, E.H. SPARC, a matricellular protein that functions in cellular differentiation and tissue response to injury. J. Clin. Invest. 2001, 107, 1049-1054. [CrossRef] [PubMed]

13. Nagaraju, G.P.; Dontula, R.; El-Rayes, B.F.; Lakka, S.S. Molecular mechanisms underlying the divergent roles of SPARC in human carcinogenesis. Carcinogenesis 2014, 35, 967-973. [CrossRef] [PubMed]

14. Kos, K.; Wilding, J.P.H. SPRAC: A key player in the pathologies associated with obesity and diabetes. Nat. Rev. Endocrinol. 2010, 6, 225-235. [CrossRef] [PubMed]

15. Raines, E.W.; Lane, T.F.; Iruela-Arispe, M.L.; Ross, R.; Sage, E.H. The extracellular glycoprotein SPARC interacts with platelet-derived growth factor (PDGF)-AB and -BB and inhibits the binding of PDGF to its receptors. Proc. Natl. Acad. Sci. USA 1992, 89, 1281-1285. [CrossRef] [PubMed]

16. Motamed, K.; Blake, D.J.; Angello, J.C.; Allen, B.L.; Rapraeger, A.C.; Hauschka, S.D.; Sage, E.H. Fibroblast growth factor receptor-1 mediates the inhibition of endothelial cell proliferation and the promotion of skeletal myoblast differentiation by SPARC: A role for protein kinase A. J. Cell. Biochem. 2003, 90, 408-423. [CrossRef] [PubMed]

17. Jayakumar, A.R.; Apeksha, A.; Norenberg, M.D. Role of matricellular proteins in disorders of the central nervous system. Neurochem. Res. 2017, 42, 858-875. [CrossRef]

18. Gilmour, D.T.; Lyon, G.J.; Carlton, M.B.; Sanes, J.R.; Cunningham, J.M.; Anderson, J.R.; Hogan, B.L.; Evans, M.J.; Colledge, W.H. Mice deficient for the secreted glycoprotein SPARC/osteonectin/BM40 develop normally but show severe age-onset cataract formation and disruption of the lens. EMBO J. 1998, 17, 1860-1870. [CrossRef]

19. Kucukdereli, H.; Allen, N.J.; Lee, A.T.; Feng, A.; Ozlu, M.I.; Conatser, L.M.; Chakraborty, C.; Workman, G.; Weaver, M.; Sage, E.H.; et al. Control of excitatory CNS synaptogenesis by astrocyte-secreted proteins Hevin and SPARC. Proc. Natl. Acad. Sci. USA 2011, 108, E440-E449. [CrossRef] [PubMed]

20. López-Murcia, F.J.; Terni, B.; Llobet, A. SPARC triggers a cell-autonomous program of synapse elimination. Proc. Natl. Acad. Sci. USA 2015, 112, 13366-13371. [CrossRef]

21. Au, E.; Richter, M.W.; Vincent, A.J.; Tetzlaff, W.; Aebersold, R.; Sage, E.H.; Roskams, A.J. SPARC from olfactory ensheathing cells stimulates Schwann cells to promote neurite outgrowth and enhances spinal cord repair. J. Neurosci. 2007, 27, 7208-7221. [CrossRef]

22. Ma, C.H.; Palmer, A.; Taylor, J.S. Synergistic effects of osteonectin and NGF in promoting survival and neurite outgrowth of superior cervical ganglion neurons. Brain Res. 2009, 1289, 1-13. [PubMed]

23. Lorber, B.; Chew, D.J.; Hauck, S.M.; Chong, R.S.; Fawcett, J.W.; Martin, K.R. Retinal glia promote dorsal root ganglion axon regeneration. PLoS ONE 2015, 10, e0115996. [CrossRef]

24. Pepeu, G.; Grazia Giovannini, M. The fate of the brain cholinergic neurons in neurodegenerative diseases. Brain Res. 2017, 1670, 173-184. [CrossRef] [PubMed]

25. Peeraully, M.R.; Jenkins, J.R.; Trayhurn, P. NGF gene expression and secretion in white adipose tissue: Regulation in 3T3-L1 adipocytes by hormones and inflammatory cytokines. Am. J. Physiol. Endocrinol. Metab. 2004, 287, E331-E339. [CrossRef]

26. Bulló, M.; Peeraully, M.R.; Trayhurn, P.; Folch, J.; Salas-Salvadó, J. Circulating nerve growth factor levels in relation to obesity and the metabolic syndrome in women. Eur. J. Endocrinol. 2007, 157, 303-310. [CrossRef] [PubMed]

27. Atanassova, P.; Hrischev, P.; Orbetzova, M.; Nikolov, P.; Nikolova, J.; Georgieva, E. Expression of leptin, NGF and adiponectin in metabolic syndrome. Folia Biol. 2014, 62, 301-306. [CrossRef] 
28. Skaper, S.D. Nerve growth factor: A neuroimmune crosstalk mediator for all seasons. Immunology 2017, 151, 1-15. [CrossRef]

29. Minnone, G.; De Benedetti, F.; Bracci-Laudiero, L. NGF and its receptors in the regulation of inflammatory response. Int. J. Mol. Sci. 2017, 18, 1028. [CrossRef]

30. Francki, A.; McClure, T.D.; Brekken, R.A.; Motamed, K.; Murri, C.; Wang, T.; Sage, E.H. SPARC regulates TGF-beta1-dependent signaling in primary glomerular mesangial cells. J. Cell. Biochem. 2004, 91, 915-925. [CrossRef] [PubMed]

31. Kupprion, C.; Motamed, K.; Sage, E.H. SPARC (BM-40, osteonectin) inhibits the mitogenic effect of vascular endothelial growth factor on microvascular endothelial cells. J. Biol. Chem. 1998, 273, 29635-29640. [CrossRef] [PubMed]

32. Meldolesi, J. Neurotrophin receptors in the pathogenesis, diagnosis and therapy of neurodegenerative diseases. Pharmacol. Res. 2017, 121, 129-137. [CrossRef] [PubMed]

33. Ravichandran, A.; Low, B.C. SmgGDS antagonizes BPGAP1-induced Ras/ERK activation and neuritogenesis in PC12 cell differentiation. Mol. Biol. Cell. 2013, 24, 145-156. [CrossRef] [PubMed]

34. Lombardi, L.; Persiconi, I.; Gallo, A.; Hoogenraad, C.C.; De Stefano, M.E. NGF-dependent axon growth and regeneration are altered in sympathetic neurons of dystrophic mdx mice. Mol. Cell. Neurosci. 2017, 80, 1-17. [CrossRef]

35. Albrecht, D.; López-Murcia, F.J.; Pérez-González, A.P.; Lichtner, G.; Solsona, C.; Llobet, A. SPARC prevents maturation of cholinergic presynaptic terminals. Mol. Cell. Neurosci. 2012, 49, 364-374. [CrossRef] [PubMed]

36. Waki, H.; Yamauchi, T.; Kamon, J.; Kita, S.; Ito, Y.; Hada, Y.; Uchida, S.; Tsuchida, A.; Takekawa, S.; Kadowaki, T. Generation of globular fragment of adiponectin by leukocyte elastase secreted by monocytic cell line THP-1. Endocrinology 2005, 146, 790-796. [CrossRef]

37. Kritas, S.K.; Saggini, A.; Cerulli, G.; Caraffa, A.; Antinolfi, P.; Pantalone, A.; Frydas, S.; Rosatt, M.; Tei, M.; Speziali, A.; et al. Neuropeptide NGF mediates neuro-immune response and inflammation through mast cell activation. J. Biol. Regulators Homeostatic agents 2014, 28, 177-181.

38. Żelechowska, P.; Agier, J.; Kozłowska, E.; Brzezińska-Błaszczyk, E. Mast cells participate in chronic low-grade inflammation within adipose tissue. Obes. Rev. 2018, 19, 686-697.

39. Demir, I.E.; Tieftrunk, E.; Schrn, S.; FriEss, H.; Ceyhan, G.O. Nerve growth factor \& TrkA as novel therapeutic targets in cancer. Biochim. Biophys. Acta 2016, 1866, 37-50.

40. Aloe, L.; Rocco, M.L.; Balzamino, B.O.; Micera, A. Nerve growth factor: Role in growth, differentiation and controlling cancer cell development. J. Exp. Clin. Cancer Res. 2016, 35, 116. [CrossRef]

41. Denk, F.; Bennett, D.L.; McMahon, S.B. Nerve growth factor and pain mechanisms. Annu. Rev. Neurosci. 2017, 40, 307-325. [CrossRef] [PubMed]

42. O'Shannessy, D.J.; Brigham-Burke, M.; Soneson, K.K.; Hensley, P.; Brooks, I. Determination of rate and equilibrium binding constants for macromolecular interactions by surface plasmon resonance. Methods Enzymol. 1994, 240, 323-349.

43. Schuster, S.C.; Swanson, R.V.; Alex, L.A.; Bourret, R.B.; Simon, M.I. Assembly and function of a quaternary signal transduction complex monitored by surface plasmon resonance. Nature 1993, 365, 343-347. [CrossRef]

44. Komagome, R.; Shuto, B.; Moriishi, K.; Kimura, K.; Saito, M. Neuronal and glial differentiation of neuroblastoma and glioma cell lines by Rho inhibitory exoenzyme C3. Neuropathology 1999, 19, 288-293. [CrossRef]

45. Fujioka, D.; Kawabata, K.; Saito, Y.; Kobayashi, T.; Nakamura, T.; Kodama, Y.; Takano, H.; Obata, J.E.; Kitta, Y.; Umetani, K.; et al. Role of adiponectin receptors in endothelin-induced cellular hypertrophy in cultured cardiomyocytes and their expression in infarcted heart. Am. J. Physiol. Heart Circul. Physiol. 2006, 290, H2409-H2416. [CrossRef] [PubMed]

(C) 2019 by the authors. Licensee MDPI, Basel, Switzerland. This article is an open access article distributed under the terms and conditions of the Creative Commons Attribution (CC BY) license (http:/ / creativecommons.org/licenses/by/4.0/). 